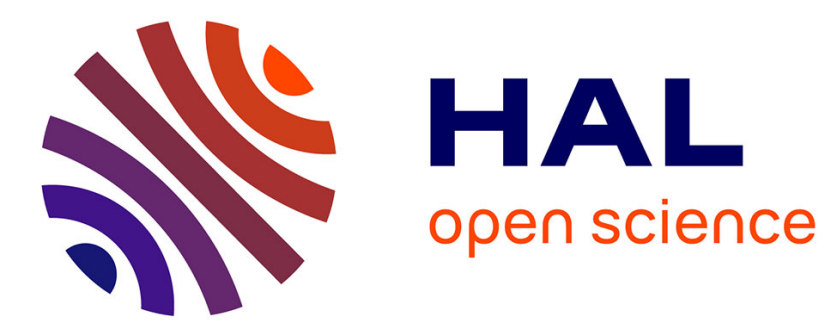

\title{
Source localization of turboshaft engine broadband noise using a three-sensor coherence method
}

\author{
D. Blacodon, S. Lewy
}

\section{To cite this version:}

D. Blacodon, S. Lewy. Source localization of turboshaft engine broadband noise using a three-sensor coherence method. The 21st International Congress on Sound and Vibration, Jul 2014, BEIJING, China. hal-01077419

\author{
HAL Id: hal-01077419 \\ https://hal.science/hal-01077419
}

Submitted on 24 Oct 2014

HAL is a multi-disciplinary open access archive for the deposit and dissemination of scientific research documents, whether they are published or not. The documents may come from teaching and research institutions in France or abroad, or from public or private research centers.
L'archive ouverte pluridisciplinaire HAL, est destinée au dépôt et à la diffusion de documents scientifiques de niveau recherche, publiés ou non, émanant des établissements d'enseignement et de recherche français ou étrangers, des laboratoires publics ou privés. 


\section{Source localization of turboshaft engine broadband noise using a three-sensor coherence method.}

D. Blacodon, S. Lewy

The 21st International Congress

on Sound and Vibration

BEIJING, CHINE

13-17 juillet 2014

TP 2014-542

\section{ONERA}

THE FRENCH AEROSPACE LAB 



\title{
Source localization of turboshaft engine broadband noise using a three-sensor coherence method.
}

\section{Localisation des sources de bruit à large bande d'un turbomoteur par une méthode de cohérence à trois capteurs.}

\author{
par \\ D. Blacodon, S. Lewy
}

\section{Résumé traduit :}

Les turbomoteurs peuvent constituer la principale source de bruit des hélicoptères au décollage. Le rayonnement vers l'amont provient surtout des raies du compresseur mais celui en aval est plus compliqué : l'émission des turbines se situe en général au-delà du domaine audible et ne contribue pas aux niveaux sonores pondérés, le jet est secondaire et son niveau sonore est faible. Une composante à large bande est la plus gênante mais ses origines sont mal connues (elle est appelée bruit interne). La présente étude a été menée dans le cadre du projet européen TEENI ("Identification du bruit d'échappement d'un turbomoteur »). L'objectif principal était de localiser les sources à large bande afin de mieux les réduire. Plusieurs techniques furent proposées par les divers partenaires. En ce qui concerne l'ONERA, une première expérience de séparation des sources fut menée dans le passé avec Turbomeca en utilisant une méthode de cohérence à trois capteurs, dont l'intérêt est d'éliminer le bruit de fond non acoustique. Grâce aux progrès en informatique, une nouvelle technique à trois capteurs, fondée sur les mêmes bases, fut mise en œuvre dans TEENI. Les mesures furent effectuées sur un turbomoteur Ardiden fortement instrumenté, dans le banc d'essai en plein air de Turbomeca. Deux puissances (approche et décollage) furent sélectionnées. Deux sondes de pression internes étaient situées dans différentes sections droites : derrière la chambre de combustion, la turbine à haute pression, le premier étage de la turbine libre ou encore dans quatre sections de la tuyère. Le troisième capteur est un microphone en champ lointain à $120^{\circ}$ de l'entrée d'air, autour de la direction du rayonnement maximum. Le principal résultat est que la cohérence augmente depuis la chambre de combustion jusqu'à la turbine à haute pression et l'entrée de la tuyère, puis diminue vers la sortie de la tuyère. Les fluctuations de pression dans la turbine à haute pression sont très cohérentes avec le spectre acoustique en champ lointain jusqu'à $700 \mathrm{~Hz}$ et constituent donc la première source de bruit (la précision décroît au-delà de $700 \mathrm{~Hz}$ parce que la cohérence est plus faible). 



\title{
The $21^{\text {st }}$ International Congress on Sound and Vibration
}

ICSV 21

13-17 July, 2014, Beijing/China

13-17 July, 2014, Beijing/China

\section{SOURCE LOCALIZATION OF TURBOSHAFT ENGINE BROADBAND NOISE USING A THREE-SENSOR COHERENCE METHOD}

\author{
Daniel Blacodon, Serge Lewy \\ National Aerospace Research Agency (ONERA), MB 72, 92322 Chatillon, France \\ e-mail: Daniel.Blacodon@onera.fr
}

Turboshaft engines can become the main source of helicopter noise at takeoff. Inlet radiation mainly comes from the compressor tones, but aft radiation is more intricate: turbine tones usually are above the audible frequency range and do not contribute to the weighted sound levels; jet is secondary and radiates low noise levels. A broadband component is the most annoying but its sources are not well known (it is called internal or core noise). Present study was made in the framework of the European project TEENI (Turboshaft Engine Exhaust Noise Identification). Its main objective was to localize the broadband sources in order to better reduce them. Several diagnostic techniques were implemented by the various TEENI partners. As regards ONERA, a first attempt at separating sources was made in the past with Turbomeca using a three-signal coherence method (TSM) to reject background non-acoustic noise. Thanks to the progress in computers, a novel TSM based on the same principles was implemented in TEENI. Measurements were made on a highly instrumented Ardiden turboshaft engine in the Turbomeca open-air test bench. Two engine powers (approach and takeoff) were selected to apply TSM. Two internal pressure probes were located in various cross-sections, either behind the combustion chamber (CC), the high-pressure turbine (HPT), the free turbine first stage, or in four nozzle sections. The third transducer was a far-field microphone located around the maximum of radiation, at $120^{\circ}$ from the intake centerline. The key result is that coherence increases from CC to HPT and at the entrance of the nozzle, then decreases in the nozzle up to the exit. Pressure fluctuations from HPT are very coherent with the far-field acoustic spectrum up to $700 \mathrm{~Hz}$ and are thus the main source of noise (accuracy decreases above $700 \mathrm{~Hz}$ because coherence is lower).

\section{Introduction}

Turboshaft engines can become the main source of helicopter noise around heliports at takeoff. $^{1,2}$ Inlet radiation mainly comes from the compressor tones, but aft radiation is more intricate. Turbine tones usually are above the audible frequency range and do not contribute to the weighted sound levels. Jet is secondary in a turboshaft engine contrary to a turbofan and emits low noise levels. A broadband component is the most annoying but its sources are not well known. It is called internal or core noise. The main objective of the European project TEENI (Turboshaft Engine Exhaust Noise Identification) was to determine its origin in order to better reduce it. Several diagnostic techniques were implemented by the various TEENI partners, such as the identification of linear and non-linear contributions, ${ }^{3}$ a modal analysis based on spectral coherences, ${ }^{4,5}$ or several 
coherence techniques for source identification (coherent output power, signal enhancement, conditional spectral analysis). ${ }^{6}$ A first attempt at separating sources was made by ONERA and Turbomeca nearly three decades ago using a three-signal coherence method (TSM) to reject nonpropagating background noise. ${ }^{7}$ Similar studies were made by Krejsa at the same period. ${ }^{8}$ The principle of the data processing was explained by Chung. ${ }^{9}$ It continues to be extended thanks to the progress in computers, ${ }^{10,11}$ and a novel method based on the same bases was implemented in TEENI. Tests are described in the next section. Then, the data processing is presented, and experimental results are discussed.

\section{Tests}

Tests were conducted at the end of January 2013 in the Turbomeca acoustic test facility located near the airport of Pau-Uzein (in South-West of France). The engine (Ardiden, left of Fig. 1) is placed on a platform, its centerline being at $3 \mathrm{~m}$ above the ground. A hydraulic brake is required to load the engine because there is no gearbox towards a rotor (engine alone).

One of the main features of the experiments is that several internal pressure probes were introduced in various cross-sections of the engine (Fig. 1, right): behind the combustion chamber (CC2), the high-pressure turbine (HPT), the first stage of the free turbine (TL1), and at four axial positions in the nozzle $(10 \mathrm{~mm}, 120 \mathrm{~mm}, 160 \mathrm{~mm}$, and $240 \mathrm{~mm}$ ) (Fig. 1, right, and Fig. 2). Two power ratings are studied here, corresponding to approach and takeoff conditions.

Conventional directivity is measured every $10^{\circ}$ in the far field on a horizontal half-circle above the concrete ground (inverted microphones), at $18.9 \mathrm{~m}$ from the engine (Fig. 3). TSM is applied to Microphone \#12 located at $120^{\circ}$ from the inlet centerline where aft noise radiation is around a maximum.
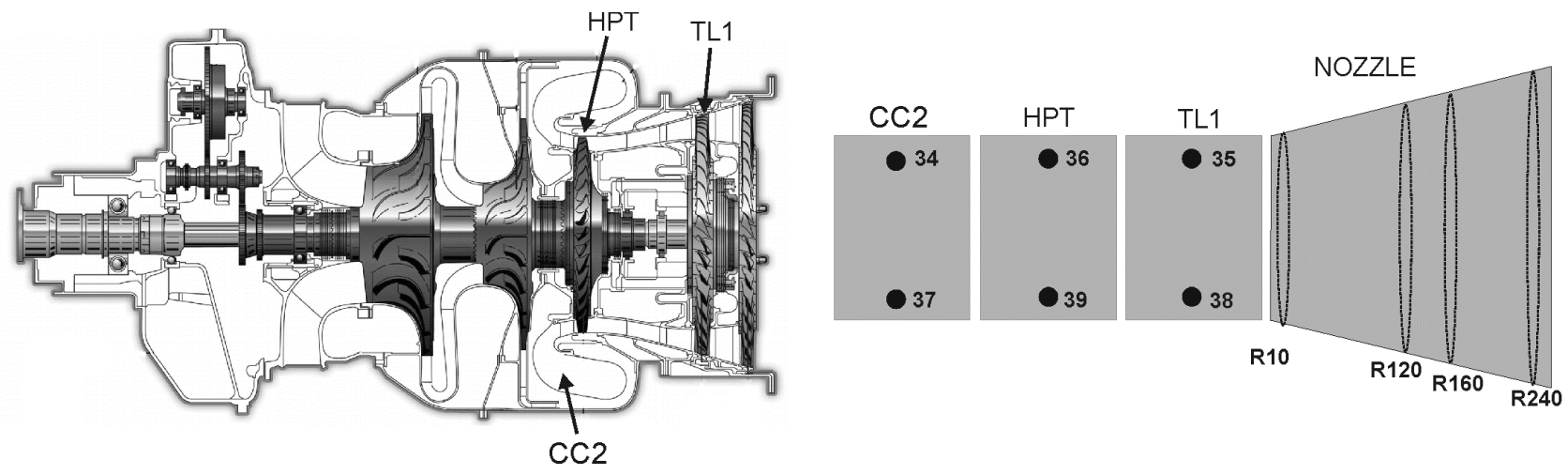

Figure 1. Schematic view of the Ardiden turboshaft engine (left), and location of internal pressure probes (right).

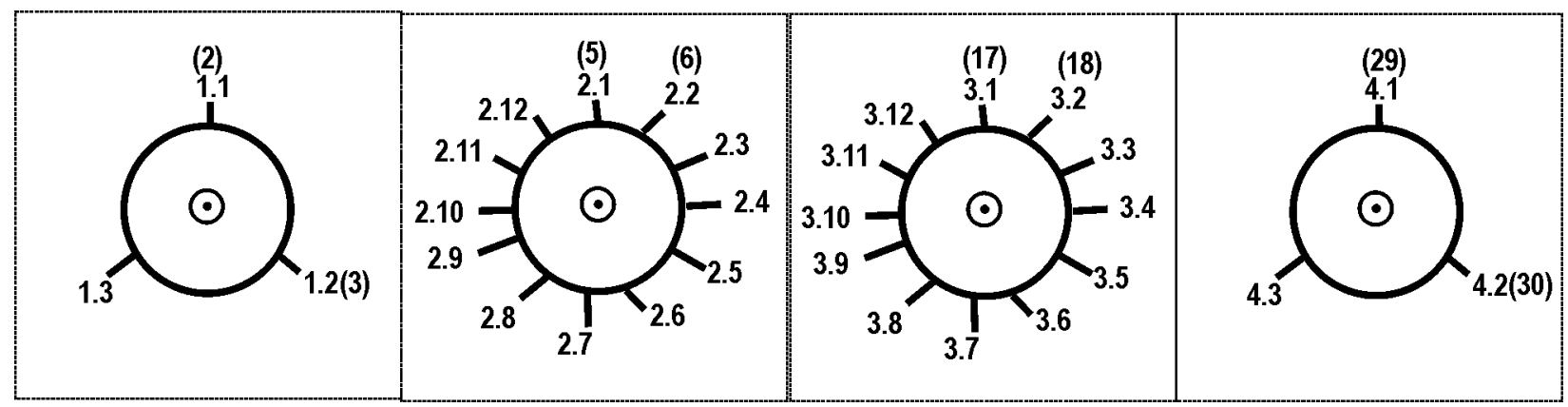

Figure 2. Azimuthal locations of the pressure probes in the four rings equipping the nozzle (numbers in parentheses are used in Figs. 9 to 11). 


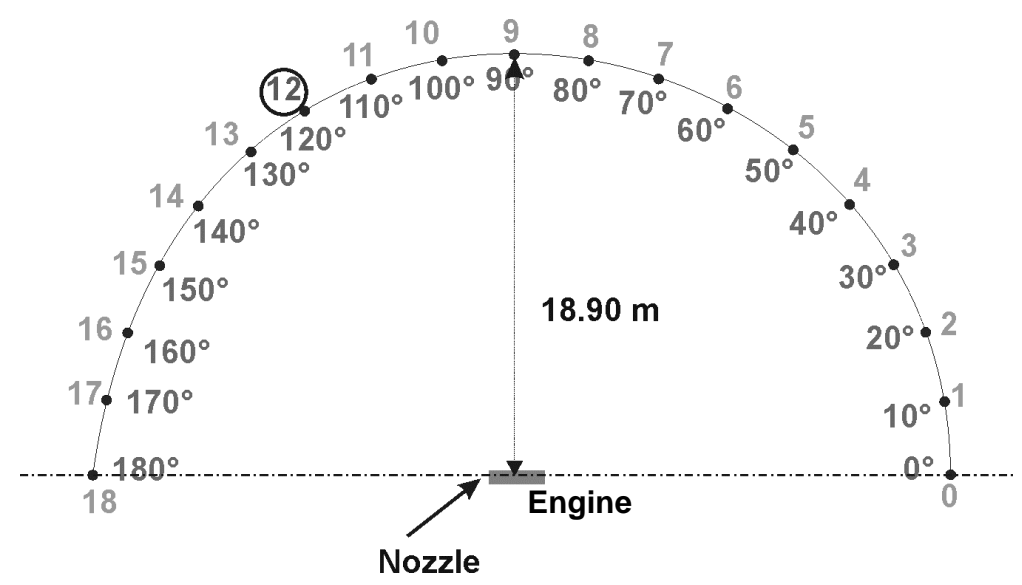

Figure 3. Locations of far-field microphones $\left(0^{\circ}\right.$ upstream).

\section{Data processing}

\subsection{Principle of the method}

Acoustic sources inside an engine can theoretically be located using cross-spectra between an internal transducer and an external microphone. However, this does not work well in practice because of the background noise on the transducer. Signal-to-noise ratio is greatly improved in the three-signal coherence technique. Two internal sensors $\mathrm{C}_{1}$ and $\mathrm{C}_{2}$ extract the acoustic power associated to a source, $\mathrm{S}$, from the spectrum measured by a far-field microphone, M. Extraction of the acoustic power of $\mathrm{S}$ is based on the following assumptions:

1. Sensor $\mathrm{C}_{1}$, located in the source region, measures the phenomenon $s(t)$ related to the acoustic source $\mathrm{S}$, plus fluctuations $n_{1}(t)$ which are assumed to be uncorrelated with $s(t)$;

2. Sensor $\mathrm{C}_{2}$, placed near $\mathrm{C}_{1}$ (in the same cross-section), measures the same function $s(t)$ with a propagation delay, plus other fluctuations $n_{2}(t)$;

3. Spurious noise $n_{1}(t)$ and $n_{2}(t)$ are uncorrelated (which implies that $\mathrm{C}_{1}$ and $\mathrm{C}_{2}$ must not be azimuthally too close);

4. The far-field microphone $M$ receives the acoustic waves radiated by the acoustic source $S$ as well as those emitted by the other sources which are considered as an additive noise $n_{M}(t)$ uncorrelated with $s(t)$;

5. The signal $s(t)$ can be seen differently by $\mathrm{C}_{1}, \mathrm{C}_{2}$, and $\mathrm{M}$, but only through linear filters $h_{1}(t)$, $h_{2}(t)$, and $h_{M}(t)$.

Let us note $p_{1}(t), p_{2}(t)$, and $p_{M}(t)$ the signals at the output of $\mathrm{C}_{1}, \mathrm{C}_{2}$, and $\mathrm{M}$, respectively, and $P_{1}(f), P_{2}(f)$, and $P_{M}(f)$ their Fourier transforms. According to the assumptions (1), (2), (4), and (5), $P_{1}(f), P_{2}(f)$, and $P_{M}(f)$ can be written:

$$
\left\{\begin{array}{l}
P_{1}(f)=H_{1}(f) S(f)+N_{1}(f) \\
P_{2}(f)=H_{2}(f) S(f)+N_{2}(f) \\
P_{M}(f)=H_{M}(f) S(f)+N_{M}(f)
\end{array}\right.
$$

where $S(f), H_{1}(f), H_{2}(f), H_{M}(f), N_{1}(f), N_{2}(f)$, and $N_{M}(f)$ are the Fourier transforms of $s(t), h_{1}(t), h_{2}(t)$, $h_{M}(t), n_{1}(t), n_{2}(t)$, and $n_{M}(t)$, respectively. The power spectral density (PSD), $\Gamma_{M}(f)$, of $p_{M}(t)$ is:

$$
\Gamma_{M}(f)=<P_{M}(f) P_{M}^{*}(f)>
$$

and:

$$
<P_{M}(f) P_{M}^{*}(f)>=<\left[H_{M}(f) S(f)+N_{M}(f)\right] \cdot\left[H_{M}(f) S(f)+N_{M}(f)\right]^{*}>,
$$

where the asterisk is the complex conjugate. Taking into account assumption (4), i.e., $s(t)$ and the additive noise $n_{M}(t)$ are uncorrelated, $\Gamma_{M}(f)$ becomes: 


$$
\Gamma_{M}(f)=\left|H_{M}(f)\right|^{2} \Gamma_{S}(f)+\Gamma_{n_{M}}(f)
$$

where $\Gamma_{S}(f)=<S(f) S^{*}(f)>$ is the $\operatorname{PSD}$ of $s(t)$ and $\Gamma_{n_{M}}(f)=<N_{M}(f) N_{M}^{*}(f)>$ denotes the PSD of the additive noise $n_{M}(t)$.

The objective is to extract from $\Gamma_{M}(f)$ the PSD associated to the acoustic source S defined by $\left|H_{M}(f)\right|^{2} \Gamma_{S}(f)$. To do that, the cross-PSD of the three signals $p_{1}(t), p_{2}(t)$, and $p_{M}(t)$ are considered:

$$
\left\{\begin{array}{l}
\Gamma_{12}(f)=<P_{1}(f) P_{2}^{*}(f)>=H_{1}(f) H_{2}^{*}(f) \Gamma_{S}(f) \\
\Gamma_{1 M}(f)=<P_{1}(f) P_{M}^{*}(f)>=H_{1}(f) H_{M}^{*}(f) \Gamma_{S}(f) \\
\Gamma_{M 2}(f)=<P_{M}(f) P_{2}^{*}(f)>=H_{M}(f) H_{2}^{*}(f) \Gamma_{S}(f)
\end{array}\right.
$$

The PSD of $\mathrm{S}$ is obtained using the three cross-PSD $\Gamma_{12}(f), \Gamma_{1 M}(f)$, and $\Gamma_{M 2}(f)$, and the following relation:

$$
G_{12}^{M}=\frac{\Gamma_{1 M}(f) \Gamma_{M 2}(f)}{\Gamma_{12}(f)}=\left|H_{M}(f)\right|^{2} \Gamma_{S}(f)
$$

This equation shows that the function $G_{12}^{M}$ depends upon neither the locations of $\mathrm{C}_{1}$ and $\mathrm{C}_{2}$ nor their characteristics. The only requirement to find the PSD of $\mathrm{S}$ is that the internal sensors $\mathrm{C}_{1}$ and $\mathrm{C}_{2}$ are sensitive to the source $\mathrm{S}$.

The question that may arise when using $G_{12}^{M}$ to estimate the PSD of S is to assess the degree of confidence of the estimation. The answer can be given by the phase $\varphi$ of $G_{12}^{M}$. Let us express $\Gamma_{12}(f), \Gamma_{1 M}(f)$, and $\Gamma_{M 2}(f)$ in their complex polar forms:

$$
\left\{\begin{aligned}
\Gamma_{12}(f)=\gamma_{12} e^{i \theta_{12}} \quad \text { with } \gamma_{12}=\left|<P_{1}(f) P_{2}^{*}(f)>\right| \\
\theta_{12}=\tan ^{-1}\left[\mathfrak{I} \mathrm{m}\left(<P_{1}(f) P_{2}^{*}(f)>\right) / \mathfrak{R} \mathrm{e}\left(<P_{1}(f) P_{2}^{*}(f)>\right)\right] \\
\Gamma_{1 M}(f)=\gamma_{1 M} e^{i \theta_{1 M}} \text { with } \gamma_{1 M}=\left|<P_{1}(f) P_{M}^{*}(f)>\right| \\
\theta_{1 M}=\tan ^{-1}\left[\mathfrak{I} \mathrm{m}\left(<P_{1}(f) P_{M}^{*}(f)>\right) / \Re \mathrm{e}\left(<P_{1}(f) P_{M}^{*}(f)>\right)\right] \\
\Gamma_{M 2}(f)=\gamma_{M 2} e^{i \theta_{M 2}} \text { with } \gamma_{M 2}=\left|<P_{M}(f) P_{2}^{*}(f)>\right| \\
\theta_{M 2}=\tan ^{-1}\left[\mathfrak{I} \mathrm{m}\left(<P_{M}(f) P_{2}^{*}(f)>\right) / \Re \mathrm{e}\left(<P_{M}(f) P_{2}^{*}(f)>\right)\right]
\end{aligned}\right.
$$

where $\Re$ e and $\mathfrak{I m}$ are the real and imaginary parts. Thus, $G_{12}^{M}$ can be written as follows:

$$
G_{12}^{M}=\frac{\gamma_{1 M} \gamma_{M 2}}{\gamma_{12}} e^{i \varphi}, \text { with } \varphi=\theta_{1 M}+\theta_{M 2}-\theta_{12}
$$

It is deduced from Eqs. (6) and (8) that $\varphi$ must be zero to find $G_{12}^{M}=\left|H_{M}(f)\right|^{2} \Gamma_{S}(f)$ in the ideal case. In practice, the quality of the extraction of the PSD of S can be assessed by comparing the deviation of the phase $\varphi$ of $G_{12}^{M}$ from a zero phase.

\subsection{Numerical simulation}

An illustration of the expected results using the three-signal method (TSM) in the TEENI project is examined in a numerical simulation described in Fig. 4. The two sensors $\mathrm{C}_{1}$ and $\mathrm{C}_{2}$ are in 
the vicinity of a source volume, S, to be characterized. S radiates in the frequency range [ $200 \mathrm{~Hz}$, $400 \mathrm{~Hz}]$ as is shown in Fig. 5.

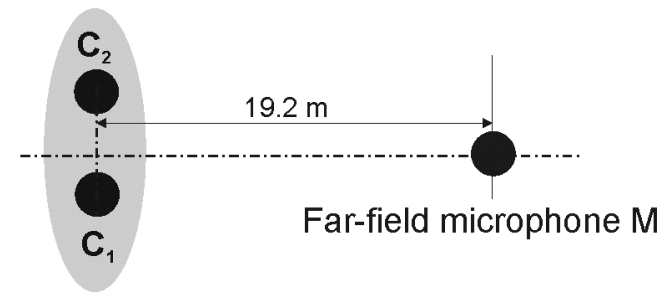

Source volume S

Figure 4. Geometry of the numerical simulation.

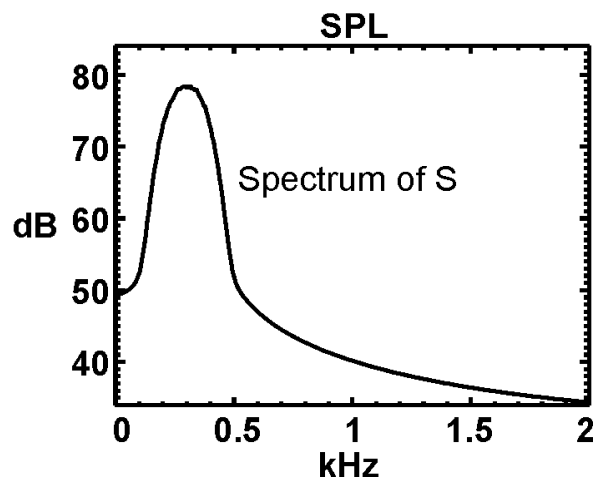

Figure 5. Signal to be restored using TSM.

In order to simulate a realistic situation, it is assumed that the acoustic pressures measured by $\mathrm{C}_{1}, \mathrm{C}_{2}$, and $\mathrm{M}$ are corrupted by background noise in the frequency band $[0,2 \mathrm{kHz}]$ whose level is much higher than the source level (Fig. 6). Furthermore, it is also assumed that the background noise measured by the two sensors is uncorrelated with the microphone background noise. TSM is thus applied to the noisy spectra measured by $\mathrm{C}_{1}, \mathrm{C}_{2}$, and $\mathrm{M}$, shown in Fig. 7 .
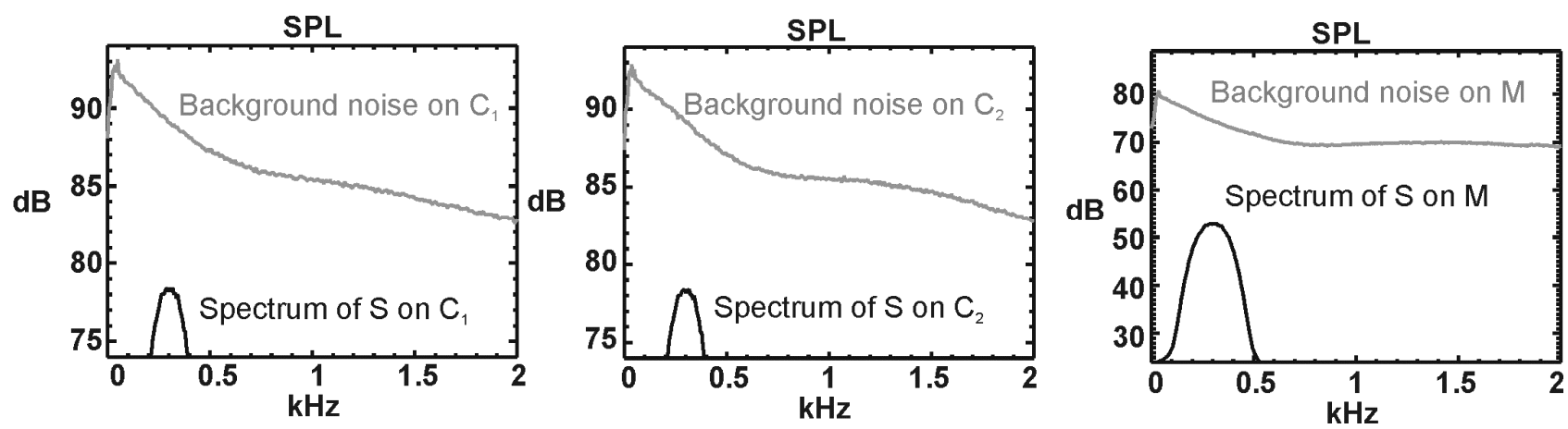

Figure 6. Background noise levels on $\mathrm{C}_{1}$ (left), $\mathrm{C}_{2}$ (center), and far-field microphone $\mathrm{M}$ (right) compared to the signal level.
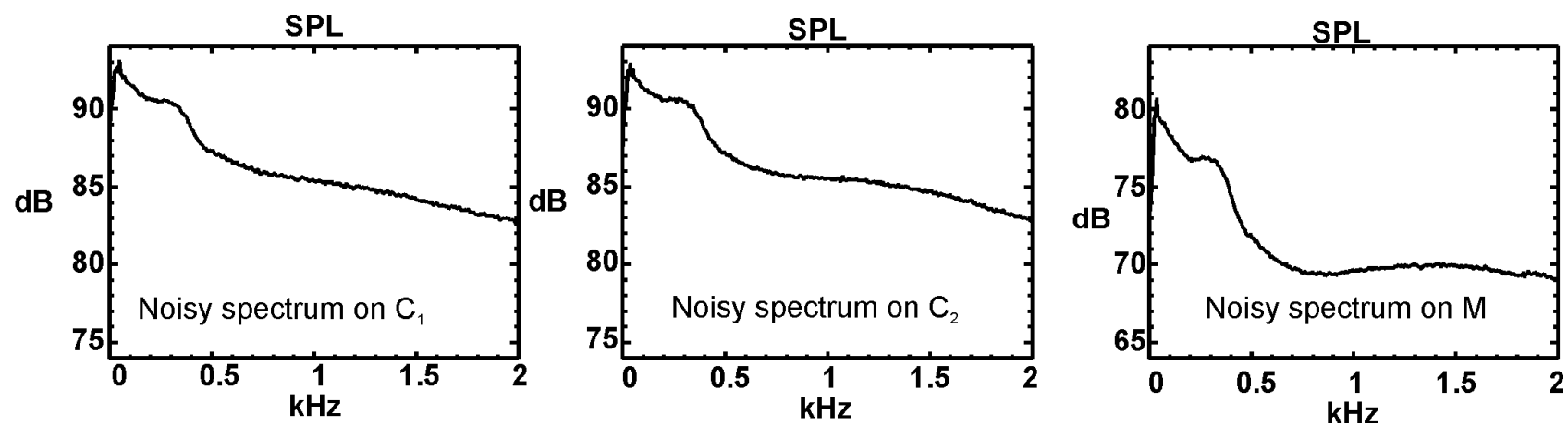

Figure 7. Noisy spectra measured by $\mathrm{C}_{1}$ (left), $\mathrm{C}_{2}$ (center), and microphone $\mathrm{M}$ (right).

Clearly, it is not possible to characterize neither the source level of $S$, nor its frequency band of radiation. The result provided by TSM (Fig. 8) exhibits a narrow-band source in the frequency band of the simulated acoustic source (left graph). It also appears that background noise level above $400 \mathrm{~Hz}$ is very low. The TSM estimate of the spectrum phase (right graph) is very erratic except in the interval $[200 \mathrm{~Hz}, 400 \mathrm{~Hz}]$ where it is zero. It can be concluded from the phase that the extraction of the source spectrum has been performed with a good accuracy. 

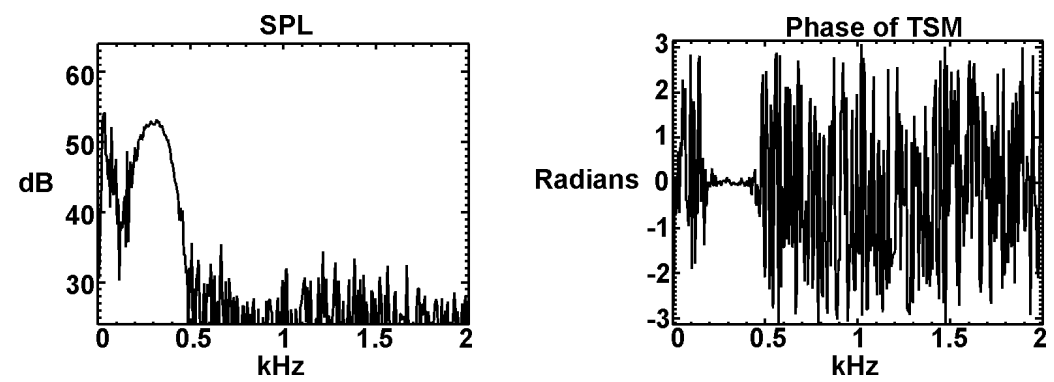

Figure 8. TSM result: estimated spectrum of S (left graph) and phase (right graph).

\section{Experimental results}

For the TSM data processing, signals from internal sensors and from the far-field microphone were digitized in 62 blocks of 4096 samples each. Sampling frequency is 25,600 Hz (i.e., resolution of $6.25 \mathrm{~Hz}$ ). Spectra are thus estimated on the duration of 9.92 seconds.

The main results of the turboshaft engine tests are displayed in Figs. 9 and 10 for approach and takeoff conditions, respectively. The far-field sound spectrum at $120^{\circ}$ is duplicated in each graph (Microphone \#12 in black). The three-signal cross-spectra between the acoustic signal and two pressure probes located in the successive cross-sections (see Figs. 1 and 2) are plotted in grey.

The highest levels of the acoustic spectra lie in the range from 0 to $1 \mathrm{kHz}$, including two main humps around $200 \mathrm{~Hz}$ and $500 \mathrm{~Hz}$. The three-signal cross-spectra remain much lower than the acoustic spectra above $700 \mathrm{~Hz}$. Indeed, the phases of the cross-spectra (Fig. 11) become very noisy above this frequency which is inconsistent with Eq. (8). In the low frequency range, cross-spectra with signals from the combustion chamber are low. They become quite equal to the acoustic spectra using the signals from the high-pressure turbine, and then slightly decrease with the transducers in the nozzle. This clearly means that the broadband component mainly comes from the high-pressure turbine. It is probably due to indirect combustion noise. ${ }^{12}$

It can be noticed that the present method is rather efficient. Figure 12 shows for instance the three spectra corresponding to the fourth graph in Fig. 9, i.e., two signals measured in the nozzle cross-section at $10 \mathrm{~mm}$, and the far-field sound pressure at $120^{\circ}$ (these spectra are plotted on $4 \mathrm{kHz}$ instead of $2 \mathrm{kHz}$ in the previous figures). It is far from being obvious that the low-frequency parts up to $700 \mathrm{~Hz}$ of the first two signals are greatly correlated with the acoustic signal.
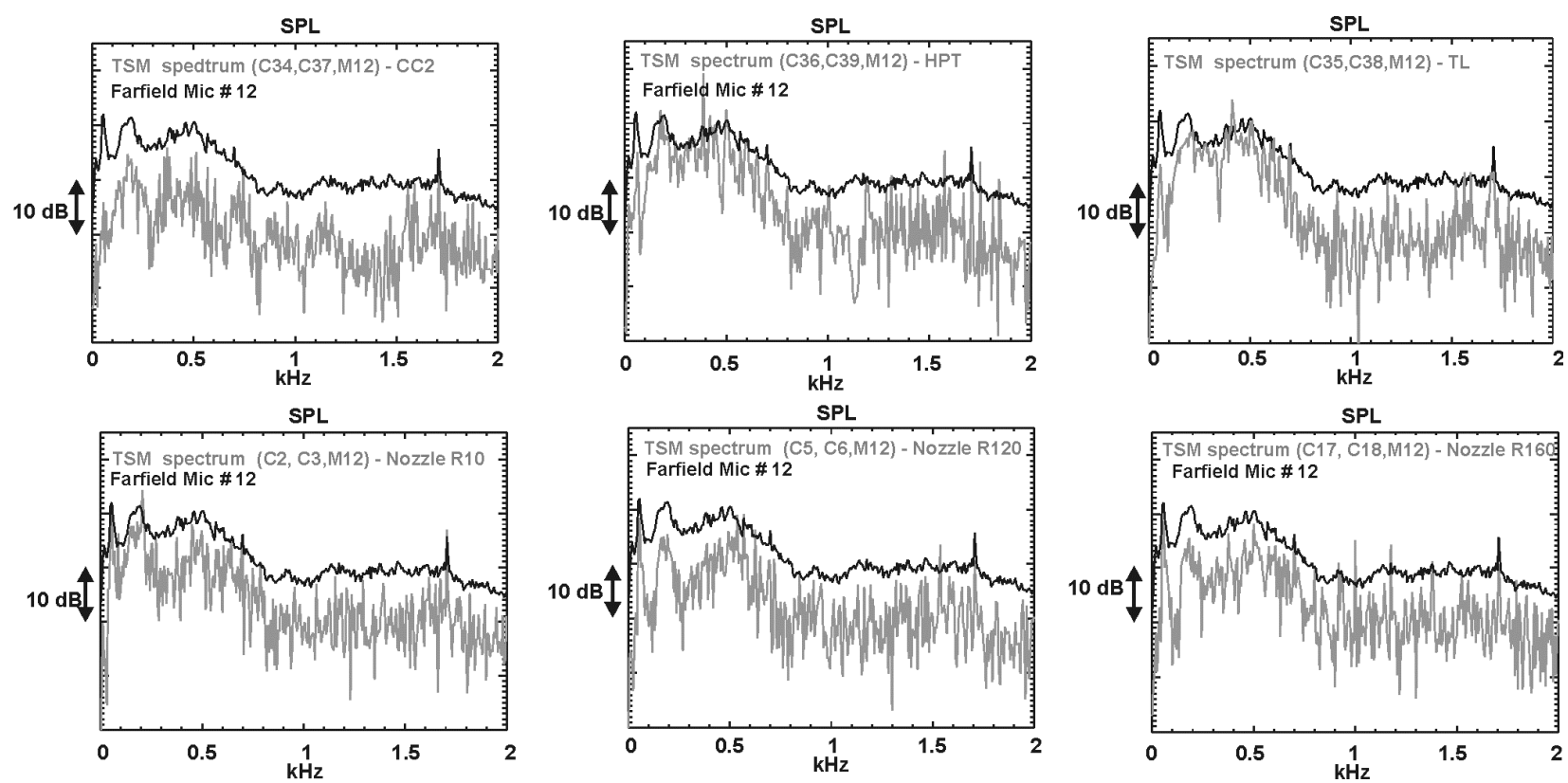

Figure 9. Far-field acoustic spectrum (in black) and three-sensor cross-spectra (in grey); approach conditions. 

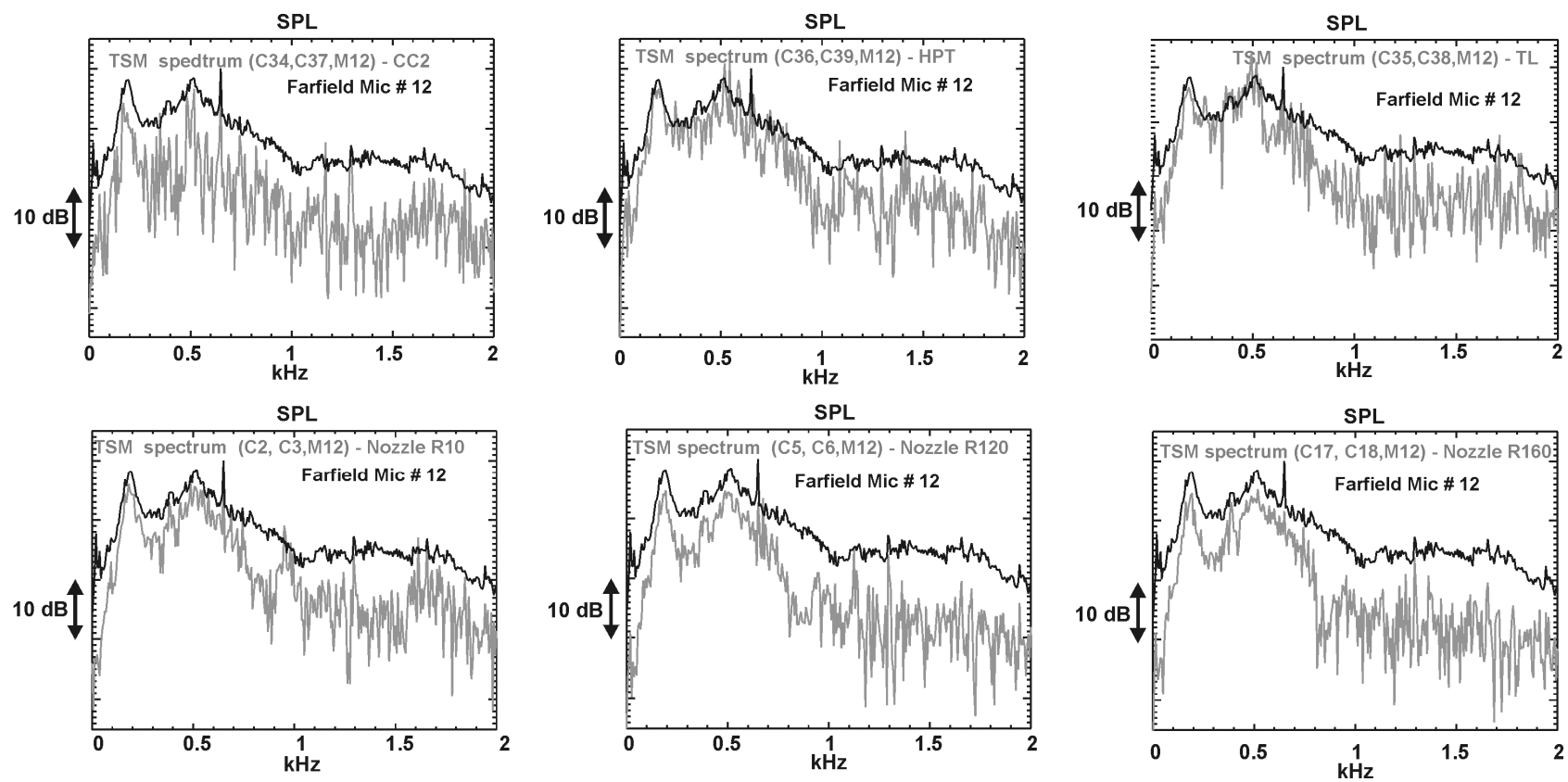

Figure 10. Far-field acoustic spectrum (in black) and three-sensor cross-spectra (in grey); takeoff conditions.
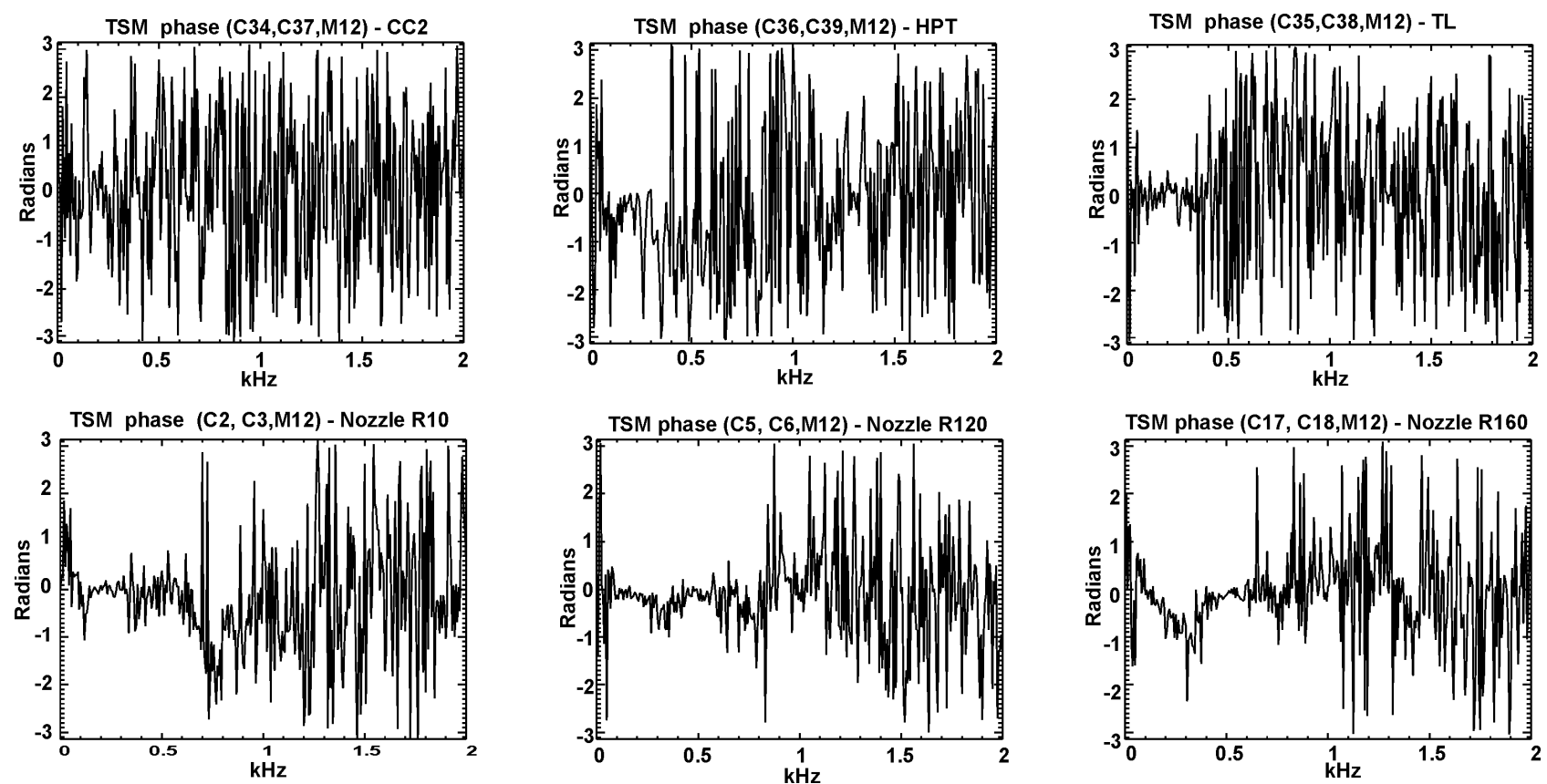

Figure 11. Phases of the three-signal cross-spectra; takeoff conditions.
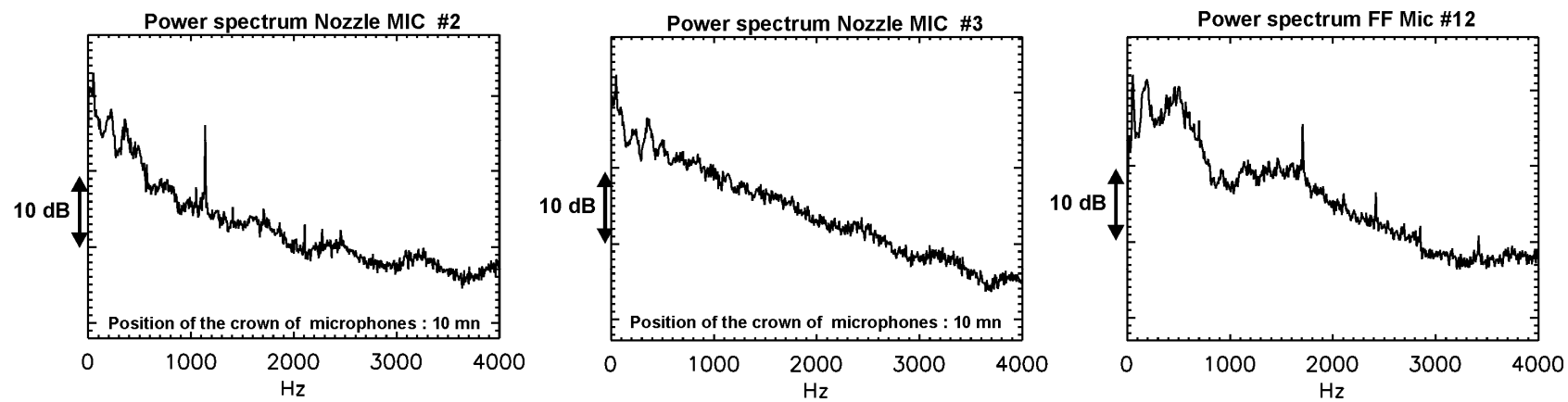

Figure 12. Spectra of the two signals at $10 \mathrm{~mm}$ in the nozzle, and of the far-field sound pressure at $120^{\circ}$; approach conditions. 


\section{Conclusions}

Internal acoustic sources in a helicopter turboshaft engine are poorly known, but they generate the aft radiated broadband noise because jet noise is secondary. Their localization is a challenge which was faced in different ways by the partners in the European project TEENI. Full-scale tests were made within this framework on a fully instrumented Ardiden engine in the Turbomeca openair facility. Present study deals with the three-sensor method implemented by ONERA. This technique makes it possible to extract the sound power levels of a source region measured locally by two sensors from the power spectral density measured by a far-field microphone. Moreover, quality of the results can be assessed by comparing the deviation of the phase at the output of the method to the zero phase. The following conclusions can be drawn from the experimental results:

- Combustion noise is identified at low frequencies and its relative importance increases behind the high-pressure turbine which means that indirect combustion noise is a major source;

- Influence of power turbine is important at higher frequencies, but is more difficult to bring out in the frequency band of interest ( 0 to $2 \mathrm{kHz})$.

Anyway, the origin of broadband noise above $2 \mathrm{kHz}$ is not fully explained (but is much lower than radiation below $1 \mathrm{kHz}$ ). However, the three-sensor method is a powerful tool in the lower frequency range to localize and quantify acoustic sources.

\section{Acknowledgements}

This work was partly supported by the project TEENI (2008-2013) funded by the European Commission in the $7^{\text {th }}$ Framework Program.

\section{REFERENCES}

1 Damongeot, A., d'Ambra, F., Masure, B. Towards a better understanding of helicopter external noise, American Helicopter Society 39th Annual Forum, St Louis, MO, 9-11 May, (1983).

2 JanakiRam, R., Smith, M. J., Tadghighi, H. Importance of engine as a source of helicopter external noise, AIAA Paper 89-1147, AIAA 12 th Aeroacoustics Conference, San Antonio, TX, 10-12 April, (1989).

3 Bennett, G., Davis, I., Tapken, U., Mahon, J. Non-linear identification applied to broadband turbomachinery noise, AIAA Paper 2010-3805, $16^{\text {th }}$ AIAA/CEAS Aeroacoustics Conference, Stockholm, Sweden, 7-9 June, (2010).

4 Bennett, G. J., O'Reilly, C., Tapken, U., Fitzpatrick, J. Noise source location in turbomachinery using coherence based modal decomposition, AIAA Paper 2009-3367, $15^{\text {th }}$ AIAA/CEAS Aeroacoustics Conference, Miami, FL, 11-13 May, (2009).

5 Jürgens, W., Tapken, U., Pardowitz, B., Kausche, P., Bennett, G. J., Enghardt, L. Technique to analyse characteristics of turbomachinery broadband noise sources, AIAA Paper 2010-3979, 16 ${ }^{\text {th }}$ AIAA/CEAS Aeroacoustics Conference, Stockholm, Sweden, 7-9 June, (2010).

6 Davis, I., Bennett, G. J. Experimental investigations of coherence based noise source identification techniques for turbomachinery applications - Classic and novel techniques, AIAA Paper 2011-2830, 17 AIAA/CEAS Aeroacoustics Conference, Portland, OR, 5-8 June, (2011).

7 Guédel, A., Farrando, A. Experimental study of turboshaft engine core noise, J. Aircraft 23 (10), 763-767, (1986).

8 Krejsa, E. A. Application of 3-signal coherence to core noise transmission, AIAA Paper 83-0759 (NASA TM-83333), AIAA $8^{\text {th }}$ Aeroacoustics Conference, Atlanta, GA, 11-13 April, (1983).

9 Chung, J. Y. Rejection of flow noise using a coherence function method, J. Acoust. Soc. Am. 62 (2), $388-$ 395, (1977).

10 Miles, J. H. Aligned and unaligned coherence: A new diagnostic tool, AIAA Paper 2006-0010 (NASA TM2006-214112), AIAA 44 ${ }^{\text {th }}$ Aerospace Sciences Meeting and Exhibit, Reno, NV, 9-12 January, (2006).

11 Miles, J. H. Spatial correlation in the ambient core noise field of a turbofan engine, J. Acoust. Soc. Am. 131 (6), 4625-4639, (2012).

12 Cumpsty, N. A., Marble, F. E. The interaction of entropy fluctuations with turbine blade rows; a mechanism of turbojet engine noise, Proceedings of the Royal Society of London, Series A, 357 (1690), 323-344, (1977). 



\section{ONERA}

BP 72 - 29 avenue de la Division Leclerc - 92322 CHATILLON CEDEX - Tél. : +33 146734040 - Fax : +33 146734141

w w w. onera.f r 